\title{
UTILIZATION OF BETEL LEAVES EXTRACT TO PREVENT THE GROWTH OF Fusarium oxysporum f.sp. capsici CAUSING FUSARIUM WILT DISEASE IN BELL PEPPER
}

\author{
Ni Wayan Anik Leana ${ }^{1} \&$ Dewa Ngurah Suprapta ${ }^{2}$ \\ ${ }^{1}$ Agrotechnology Study Program, Faculty of Agriculture, Universitas Jenderal Soedirman, Indonesia \\ Jl. DR. Soeparno No.63, Karang Bawang, Grendeng, Jawa Tengah 53122 \\ ${ }^{2}$ Agrotechnology Study Program, Faculty of Agriculture, Universitas Udayana, Indonesia \\ Jl. Kampus Unud, Bukit Jimbaran, Kuta Selatan, Badung 80362 \\ E-mail: leana@unseod.ac.id
}

Manuscript received: 7 September 2020. Revision accepted: 17 November 2020.

\begin{abstract}
Utilization of betel leaves extract to prevent the growth of Fusarium oxysporum $f$.sp. capsici causing fusarium wilt disease in bell pepper. Betel (Piper betle Linn.) is commonly used in Indonesian traditional medicine due to its antimicrobial properties, thus it is often used as an ingredient in natural pesticides. The effectiveness of betel leaf extract as a control for Fusarium oxysporum in several plants showed it's potential to control the fungi in bell pepper. F. oxysporum f.sp. capsici is one of the important pathogens causing Fusarium wilt disease in bell pepper. It is one of the most devastating plant diseases due to its ability to cause a crop failure. The test on the inhibitory capacity of betel leaf extract on the growth of $F$. oxysporum f.sp. capsici were carried out by growing the fungi on PDA mixed with various concentrations of betel leaf extracts. The results showed that betel leaf extract treatment at $0.02 \%$ concentration was able to inhibit the growth of F. oxysporum f.sp. capsici in PDA at $95.54 \%$. The full inhibition of colony growth $(100 \%)$ was achieved in the extract treated with the concentration of $0.03 \%$. Meanwhile treatment of $0.17 \%$ betel leaf extract was able to inhibit the growth of $F$. oxysporum f.sp. capsici on bell pepper stems. Following this result, fractionation of the betel leaf extract by column chromatography was conducted, resulting in 44 fractions. The bioassays of those fractions showed that, there were seven fractions that reveal inhibition capability against $F$. oxysporum f.sp. capsici.
\end{abstract}

Key words: betel, antifungal, F. oxysporum f.sp. capsici, natural pesticide

\section{INTRODUCTION}

The use of betel leaf extract (Piper betle L.) as natural fungicide to control several plant pathogenic fungi has been widely used. Several reports have shown that betel leaf extract was effective in suppressing the development of several types of pathogens. Betel leaf extract contains various active ingredients that have antimicrobial properties (Datta et al., 2011), such as alkaloids, fatty acids, phenols, alcohol, flavonoids, terpenes, coumarin, and organic acids (Foo et al., 2015). Betel leaf extract and galangal rhizome at a concentration of $0.5 \%$ were reported to be effective in inhibiting F. oxysporum and Ralstonia solanacearum bacteria in banana seeds (Phabiola, 2004). While the betel leaf extract of Beleng cultivar at the same concentration was able to inhibit the colony growth of F. oxysporum f.sp. vanillae as $83.14 \%$ (Subrata \& Rai, 2019).
Various reports on the effectiveness of betel leaf extract in controlling $F$. oxysporum in several plants indicated that, betel leaf extract was predicted to be able to control the fungus in bell pepper. F. oxysporum f.sp. capsici is one of the important pathogens causing Fusarium wilt disease in peppers. This disease is one of the most harmful diseases that can cause crop failure (Cahyono, 2003).

A preliminary study was conducted to ensure the consistency of crude extract of betel leaf's ability to inhibit the growth of the colonies of $F$. oxysporum f.sp. capsici in vitro on PDA media and bell pepper stems. The result showed that crude extract of betel leaf against F. oxysporum f.sp. capsici was able to produce an inhibition zone of $34.5 \mathrm{~mm}$. According to Morales et al. (2003), such diameter of inhibition zone was categorized into very strong. This research was conducted to ensure the consistency of extract of betel leaf's ability to inhibit 
the growth of the colonies of $F$. oxysporum f.sp. capsici in vitro on PDA media and bell pepper stems.

\section{MATERIALS AND METHODS}

Research Site. This research was conducted from August 2018 to March 2019 at the Biopesticide Laboratory in Agriculture Faculty, Udayana University.

Extraction. The extract of betel leaf was obtained by maceration using methanol as a solvent. The clean betel leaves were chopped into small pieces and dried for $2-$ $3 \mathrm{~d}$. The dried betel leaves were macerated in methanol in the ratio of 1:10 (100 g of betel leaf to $1000 \mathrm{~mL}$ of methanol). Maceration was carried out at room temperature for $48 \mathrm{~h}$. The filtrate was obtained by filtering through four layers of gauze and Whatman No. 1 filter paper. The solvent was evaporated using a rotary vacuum evaporator at a temperature of $40^{\circ} \mathrm{C}$, until the solvent separated, and the methanol extract of betel leaf was obtained.

Inhibition Ability of Betel Leaf Extract Against F. oxysporum f.sp. capsici.

The Minimum Inhibitory Concentration (MIC) Test. The MIC of betel leaf extract against $F$. oxysporum f.sp. capsici was carried out on PDA media by placing paper discs that had been previously dipped in crude extract of betel leaf with a serial concentration of $0.1 \%$, $0.25 \%, 0.5 \%, 0.75 \%, 1.0 \%$. The extracts of various concentrations were prepared by diluting the crude extract of betel leaf using acetone as a solvent. The dipped paper disc was placed in the middle of the PDA mixture (10 mL PDA and $200 \mu \mathrm{L}$ fungal suspension) in petri dish.

The Inhibition Test on PDA Mixture. The inhibition ability of betel leaf extract on the growth of F. oxysporum f.sp. capsici was carried out by growing the fungi on PDA mixed with various concentrations of betel leaf extracts. The treatments consisted of $0.10 \%$, $0.20 \%, 0.30 \%, 0.40 \%, 0.50 \%$ and $0 \%$ (negative control). These concentrations were obtained by pouring a $1 \mathrm{~mL}$ of extract of each proportions to a $9 \mathrm{~mL}$ warm PDA (temperature $\pm 50^{\circ} \mathrm{C}$ ) on petri dish, then rotating the petri dish in a circular motion until the media and extract were evenly mixed and solidified. The final concetration of the mixtures became $0.01 \%, 0.02 \%, 0.03 \%, 0.04 \%$, $0.05 \%$, and $0 \%$. Then a 4 days isolate of $F$. oxysporum f.sp. capsici were placed into the solidified PDA mixture, using a $5 \mathrm{~mm}$ diameter cork borer and a transfer needle.

Inhibition Test on Bell Pepper Stem. The tests to determine the inhibition ability of betel leaf extract on the growth of $F$. oxysporum f.sp. capsici on bell pepper stems was carried out in vitro in $30 \mathrm{~mL}$ Potato Dextrose Broth (PDB) media. PDB was mixed with $200 \mu \mathrm{L}$ of conidial suspension $\left(2 \times 10^{6}\right.$ conidia $\left./ \mathrm{mL}\right)$ and crude extract of betel leaf, on a petri dish. Extract of betel leaves as treatments with concentrations of $0.1 \%, 0.2 \%$, $0.3 \%, 0.4 \%$, and $0.5 \%, 1 \mathrm{~mL}$ each was added to the $29 \mathrm{~mL}$ PDB media. The final concentrations of the media-extract mixtures were were $0.003 \%, 0.006 \%$, $0.010 \%, 0.013 \%$, and $0.017 \%$.

Healthy stems of bell peppers were washed with distilled water and disinfected in $70 \%$ alcohol for $2 \mathrm{~min}$. After that, the bell pepper stems were washed using sterile water three times and cut into cross-sections at a length of $\pm 1 \mathrm{~cm}$. The chopped stems were put in a petri dish, 10 pieces each. As comparisons, a negative control (PDB media, without fungal suspension and extract) were used along with positive controls (PDB media, with fungal suspension only).

Separation of Methanol Phase and n-Hexane Phase of Betel Leaf Extract. The separation of the extract from the $n$-hexane and methanol phases was carried out by dissolving $4 \mathrm{~mL}$ of methanol extract of betel leaf into a mixture of $200 \mathrm{~mL}$ of methanol and $200 \mathrm{~mL}$ of n-hexane. It was shaken in a separate funnel until it was evenly mixed. The mixture then incubated for 10 min until it showed separation between methanol and n-hexane phases. After the two phases were separated, the solvent was evaporated in a vacuum rotary evaporator. Both phases were tested for inhibition ability against $F$. oxysporum f.sp. capsici on PDA media (Darmadi, 2015).

\section{Active Component Fractionation (Column Chromatography and Thin Layer} Chromatography). Fractionation of the active component of betel leaf extract was obtained by column chromatography. The column was passed through eluents with different levels of polarity (n-hexane, dichloromethane, ethyl acetate, acetone, and methanol). The stationary phase used in thin layer chromatography was silica gel (wako gel, particle size 75-150 $\mu \mathrm{m}$ ). Thin Layer Chromatography (TLC) was performed by dropping each fraction on a $10 \times 10 \mathrm{~cm}$ TLC plate (Keisal Gel 60 F254) using a capillary tube to form spots. 
The TLC plate was inserted into the TLC chamber equipped with eluent. The eluent used in this study was n-hexane: ethyl acetate (20:3). The process was ended after the top side of the eluent reached $3 / 4$ of the plate height. The TLC plate was taken out and dried, then the spots weres identified by placing the plate into a chamber containing iodine crystals. The iodine vapor caused the spots in TLC plate to change color to slightly brownish so that the TLC results could be observed.

To compare one spot with another from the separation by Thin Layer Chromatography, the retention factor ( $\mathrm{Rf}$ ) unit value was used. The value of $\mathrm{Rf}$ is the ratio of the distance from the starting point of the spot to the extent that the spot compared to the distance from the solvent to the highest point calculated from the starting point.

\section{RESULTS AND DISCUSSION}

\section{The Inhibition Ability of Betel Leaf Extract Against} F. oxysporum f.sp. capsici. Minimum Inhibitory Concentration (MIC) of betel leaf extract against F. oxysporum f.sp. capsici was at $0.1 \%$ (Table 1 ). MIC is defined as the lowest concentration of antimicrobials compounds that can inhibit microorganisms after a certain incubation period (Andrews, 2001). Suprapta \& Khalimi (2012) reported that betel leaf extract had the same antifungal activity against $F$. oxysporum f.sp. capsici with an MIC of $0.3 \mathrm{mg} / \mathrm{mL}$. The variability of antifungal activity was related to the secondary metabolites produced by the plants, whereas the production of secondary metabolites in plants was influenced by the stress level of the plant (Pagare et al., 2015). Environmental factors such as water stress could increase secondary metabolites in plants. The response of plants to water stress in addition to reducing growth and productivity could also increase levels of K, proline amino acids, and the content of secondary metabolites (Trisilawati \& Pitono, 2012). Abdelmajeed et al. (2013) reported that water deficiency treatment increased total phenolic content and antioxidant activity in Cuminum cyminum L. seeds. The effect of water deficiency in increasing secondary metabolic activity would improve the quality and efficacy of Simplicia, a medicinal plant. Rahardjo et al. (1999) reported that water stress on Sonchus arvensis caused an increase of leaf flavonoid levels by $2.11 \%$.

In this study, the leaf extract of betel leaf with a concentration of $0.02 \%$ inhibits the growth of colonies of $F$. oxysporum f.sp. capsici at $95.54 \%$. This showed that the leaf extract of betel leaf has the ability to inhibit the growth of $F$. oxysporum f.sp. capsici mycelia. The $100 \%$ inhibition was shown at the concentration of $0.03 \%$ (Table 1). This result is in line to Sanit (2016) which demonstrated that $0.10 \%$ betel leaf extract was able to inhibit the growth of mycelia Fusarium sp. amounted to $58.00 \%$, while the $100 \%$ inhibition was shown in the extract treatment of $0.25 \%$. Other study also reported that the $1.00 \%$ concentration of betel leaf extract had the ability to suppress $100 \%$ of the growth of $F$. oxysporum mycelia (Singburaudom, 2015).

The growth of colony F. oxysporum f.sp. capsici can already be seen after $2 \mathrm{~d}$ of incubation on PDA media with no treatment and it become fully grown after $11 \mathrm{~d}$ of incubation (Figure 1). Colony growth of F. oxysporum f.sp. capsici on media containing of betel leaf began extract to appear on the 4 th day $(0.01 \%$ extract treatment) and 10 th day $(0.02 \%$ extract treatment) after inoculation. While the treatments of betel leaf extract with a concentration of $0.03 \% ; 0.04 \%$; and $0.05 \%$ did not show any growth of $F$. oxysporum f.sp. capsici. Arsih et al. (2015) reported that betel leaf extract at concentration of $0.25 \%$ also reported to be able to suppress the growth of $F$. oxysporum f.sp lycopersici causing Fusarium wilt disease in tomatoes by $68.89 \%$.

The results growth of $F$. oxysporum f.sp. capsici on bell pepper stems in vitro in PDB media showed that in the positive control, $0.003 \%, 0.006 \%$, and $0.010 \%$ the disease symptoms appeared on the 3rd day of incubation (Table 2). Whereas the treatment with $0.013 \%$ extract, the symptoms was appeared after 4th day.

Table 1. Inhibition ability of betel leaf extract against $F$. oxysporum f.sp. capsici

\begin{tabular}{ccc}
\hline Concentration $(\%)$ & Average colony diameter $(\mathrm{mm}) *$ & Inhibition rate $(\%)^{*}$ \\
\hline 0 & 89.67 & 0 \\
0.01 & 29.00 & 67.66 \\
0.02 & 4.00 & 95.54 \\
0.03 & - & 100 \\
0.04 & - & 100 \\
0.05 & - & 100 \\
\hline
\end{tabular}

$*=11$ days of incubation 
Different results were shown by $0.017 \%$ extract treatment and negative control, in which fungal growth did not start to appear until 4th days after incubation (Figure 2). In vitro test using bell pepper stems showed that the fungus grew first on the stems, then spread on the media.

Inhibition Ability of Methanol and n-Hexane Phase of Betel Leaf Extract Against $F$. oxysporum f.sp. capsici. Separation of betel leaf extract into methanol and n-hexane phases resulted in different inhibition of $F$. oxysporum f.sp. capsici. The methanol phase showed a larger diameter of inhibition zone than the nhexane phase. Methanol phase and n-hexane phase showed a diameter of inhibition of $16.33 \mathrm{~mm}$ and $6.67 \mathrm{~mm}$, respectively. This showed that the betel leaf extract in the methanol phase has greater inhibition ability against $F$. oxysporum f.sp. capsici.

Betel leaf extract macerated with a $1 \%$ concentration of chloroform solvent was reported to be effective in reducing the population of $F$. oxysporum f.sp. lycopersici in the rhizosphere of tomato was grown compared to treatment with the synthetic fungicide carbendazim (Singha et al., 2011). Besides chloroform solvent, ethanol and acetone extract of betel leaves with a concentration of $20 \%$ (Neela et al., 2014), diethyl ether and ethyl acetate extract of betel leaves (Murugesan et al., 2011) were also effective in inhibiting the growth of $F$. oxysporum. A study in Fusarium wilt in banana demonstrated that betel leaf extracts from maceration processes using ethyl acetate, methanol, n-hexane also showed antifungal properties against

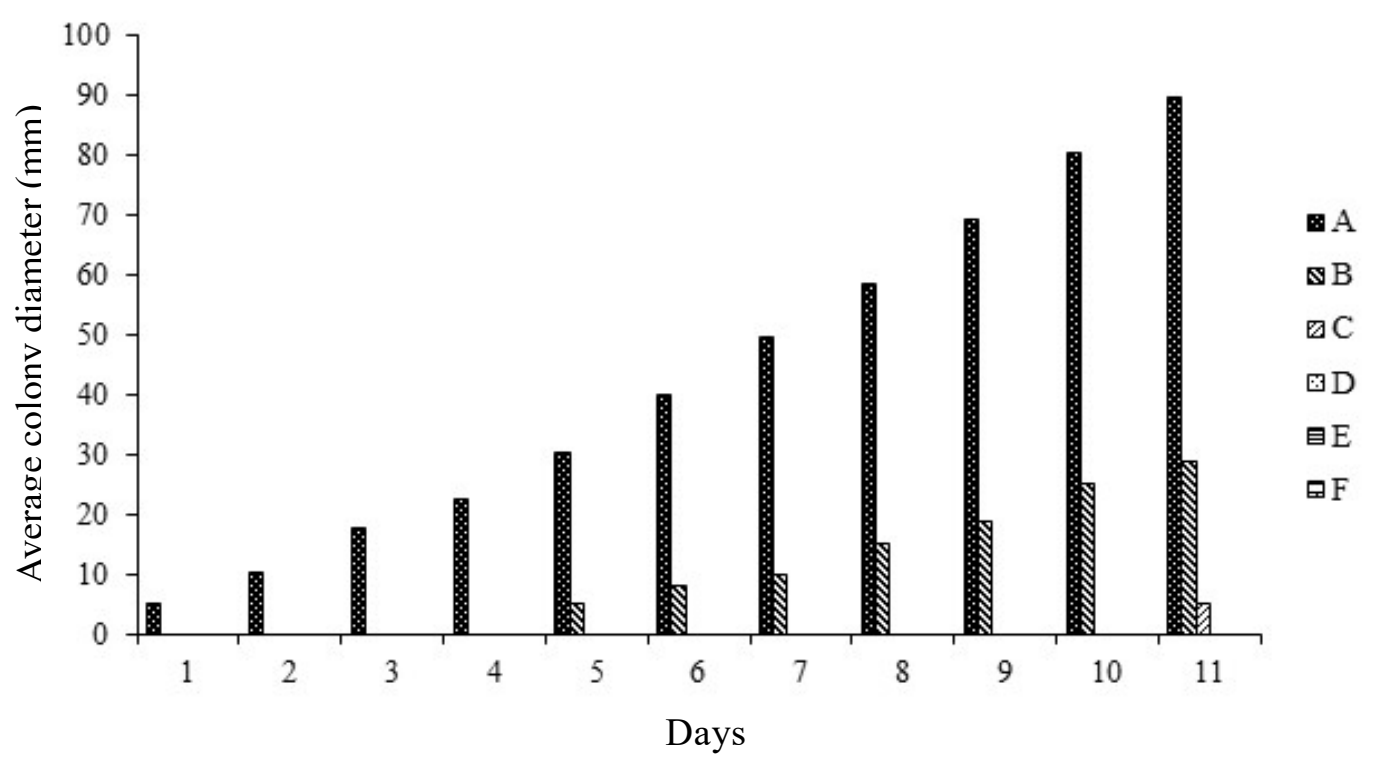

Figure 1. Growth of F. oxysporum f.sp. capsici on PDA media with the concentration of betel leaf extract. (A) $0 \%$; (B) $0.01 \%$; (C) 0.02\%; (D) 0.03\%; (E) 0.04\%; (F) $0.05 \%$.

Table 2. Growth of F. oxysporum f.sp. capsici on PDB media with various concentrations of betel leaf extract

\begin{tabular}{ccccccccc}
\hline & \multicolumn{7}{c}{ Extract concentration (\%) } \\
\cline { 2 - 7 } Days & 0 & 0 & 0.003 & 0.006 & 0.010 & 0.013 & 0.017 \\
& Negative control & Positive control & - & - & - & - & - & - \\
\hline 1 & - & - & - & - & - & - & - \\
2 & - & ++ & + & + & + & - & - \\
3 & - & ++++ & +++ & ++ & + & + & - \\
\hline
\end{tabular}

$(-) \quad=$ The fungi did not grow neither in the bell pepper stems nor in the PDB

$(+) \quad=$ The fungi grew in the surface of bell pepper stems

$(++) \quad=$ The fungi grew in the whole of bell pepper stems

$(+++)=$ The fungi grew in the media

$(++++)=$ The fungi filled the media 
F. oxysporum f.sp. cubense with methanol extraction result exhibiting the highest inhibitory (Gnanasekaran et al., 2015).

That study was in line with Aoki et al. (2019), in which methanol extract of betel leaf showed stronger antifungal activity than betel leaf hot water extract with a concentration of $10 \%$ against Plasmopara viticola causing downy mildew in grapes.

Patil et al. (2015) stated that betel leaf extract contained various antimicrobial active ingredients as well. The water, ethanol, methanol, butanol, and acetone extracts of betel leaves each had antimicrobial activity against several fungi and bacteria, however the methanol and butanol extracts showed stronger antimicrobial activity. This shows that the antifungal active compounds in betel extract consist of several active compounds that have different polarity, but the antifungal activity is stronger in the methanol phase extract which has polar properties.

Inhibition Ability of Betel Leaf Extract Fraction Against $\boldsymbol{F}$. oxysporum f.sp. capsici. Fractionation of the betel leaf extract by column chromatography resulted in 44 fractions. Testing of $F$. oxysporum f.sp. capsici was carried out on those 44 fractions. The results showed that, there were seven fractions showing the inhibition capability against $F$. oxysporum f.sp. capsici namely F9, F10, F11, F12, F13, F19, and F20 (Figure 3; Table 3).

Thin Layer Chromatography (TLC) was carried out on these seven fractions to determine the best eluent as a separator for the active antifungal compound of F. oxysporum f.sp. capsici. The TLC results showed that the best eluent was mixture of n-hexane: ethyl acetate (20:3) (Figure 3).

Based on the Rf value, there were seven different fractions (Table 3$)$. There were fractions F10 $(\mathrm{Rf}=$ $0.55)$ and $F 20(R f=0.13)$ that had single $R f$ value meaning that the fractions probably contained single groups of compounds. Meanwhile, there were fractions that had multiple Rf values one such as F9, F11, F12, F13, and F19 and probably each contained more than one compound. These fractions probably contained similar groups of compounds (F13 and F19 have the same Rf value, namely 0.08 and 0.16 ). There were also groups of fractions consisting of different types of compounds (F13 contained a group of compounds that were not present in F19 indicated by the Rf value of 0.23 , and vice versa F19 contained a group of compounds that were not present in F13 notified by $\mathrm{Rf}$ value of 0.29 ).

The diameters of the inhibition zones produced by the fractions were also different. For example, fraction F19 had a larger diameter of inhibition than fraction F11. This was presumably due to the different types of active compounds in the two fractions as well as differences in the synergy of active compound groups in these fractions. The fractions F9, F11, F12, F13, and F19 had more than one Rf value, indicating that the active ingredients in the fractions probably consisted of two or more groups of active compounds.

Betel leaf extract contained various active ingredients that have antimicrobial properties (Datta et al., 2011). The antifungal in methanol extract of betel leaves was produced from a mixture of more than two compounds (Aoki et al., 2019). The same phenomenon

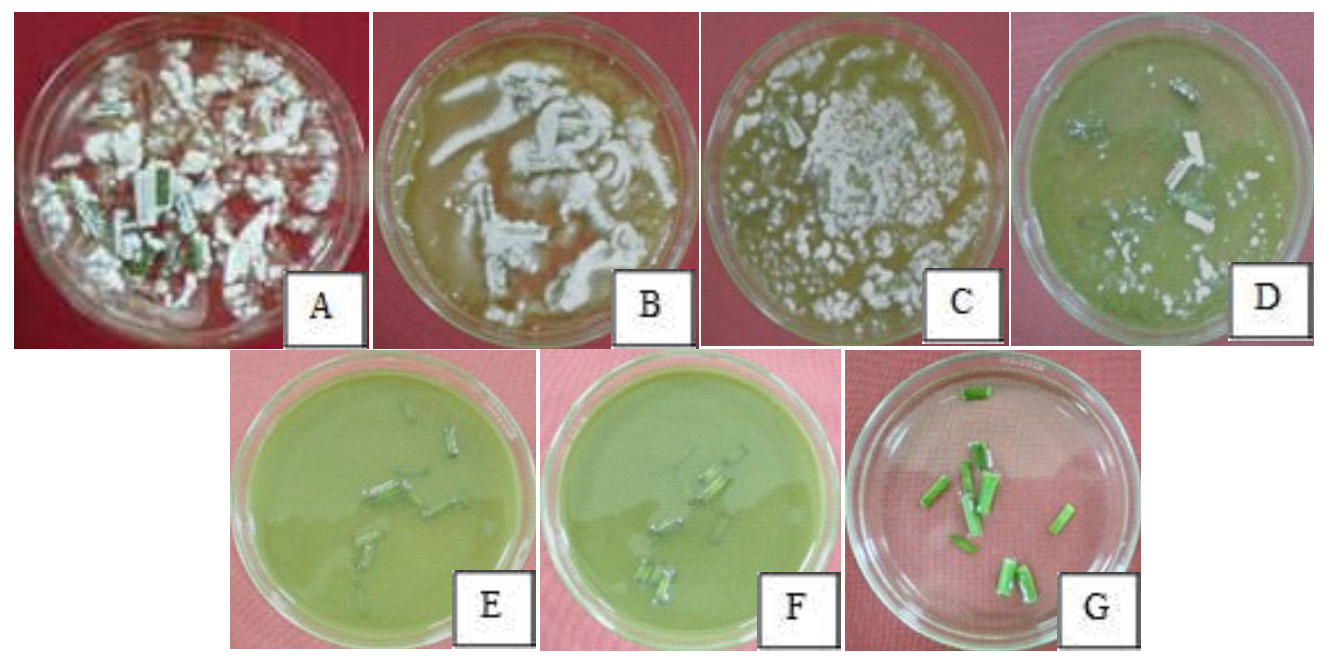

Figure 2. Growth of $F$. oxysporum f.sp. capsici on the PDB with various treatments after 3 days of incubation. (A) positive control, (B) 0.003\% extract, (C) 0.006\%, (D) 0.010\%, (E) 0.013\%, (F) 0.017\%, (G) negative control. 
happened to betel leaves extracted with other organic solvents. Chloroform extract of betel leaves contained terpenoids, saponins, phlobatanins, flavonoids, phytosterols, phenols, and tannins (Singha, 2011). Gas chromatography-mass spectroscopic analysis (GC-MS) of betel leaf extract showed the content of alkaloids, fatty acids, phenols, alcohols, flavonoids, terpenes, coumarin, and organic acids (Foo et al., 2015).

Rongai et al. (2014) reported that the relationship between Total Phenolic Content (TPC) in several extracts was related to the ability to inhibit the growth of $F$. oxysporum mycelia. Plant extracts having strong antifungal activity are generally high in phenols. In line with this, Singburaudom (2015) stated that, betel leaves contained phenols with the active compound of hydroxychavicol having a fungistatic and fungicidal effect on plant pathogenic fungi. Similar results were reported by Ali et al. (2010) stating that, hydroxychavicol from betel leaf showed antifungal activity against the 124 tested fungi.

The anti-fungal activity of the fractionated betel leaf extract was higher than the anti-fungal activity of the crude extract. This could be seen from the F19 fraction test that created $39.33 \mathrm{~mm}$ of inhibition zone, while the crude extract in the preliminary test only produced $34.5 \mathrm{~mm}$ of inhibitin zone. The larger diameter of inhibition zone after fractionation was probably due to the pure active compound resulting from the fractionation, as well as the lack of anti-synergy among the various compounds contained in the crude extract of the betel leaves.

Inhibitory ability of betel leaf extract against F. oxysporum f.sp. capsici showed that the plant had the potential to be developed as a natural pesticide. Various antifungal active compounds in betel leaf extract gave the advantage in the application of natural pesticides in the field, because various active compounds will reduce the resistance of pathogens. Further research is needed to determine the antifungal compounds in the betel leaf extract, especially against $F$. oxysporum f.sp. capsici.

\section{CONCLUSION}

Methanol extract of betel leaves effectively inhibited the growth of $F$. oxysporum f.sp. capsici with

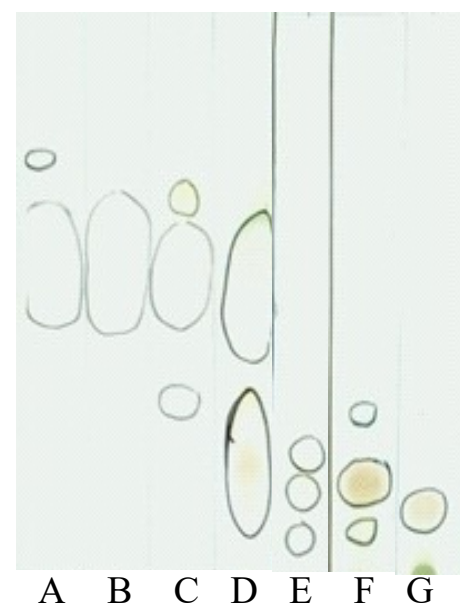

Figure 3. Spots on TLC. (A) F9; (B) F10; (C) F11; (D) F12; (E) F13; (F) F19; (G) F20.

Table 3. The inhibition ability of each fraction of betel leaf extract against $F$. oxysporum f.sp. capsici

Fraction number Diameter of inhibition zone Rf $(\mathrm{mm})$

\begin{tabular}{lll}
\hline F9 & 10.67 & Rf $1=0.55 ; \operatorname{Rf} 2=0.74$ \\
F10 & 8 & Rf $=0.55$ \\
F11 & 6 & Rf $1=0.31 ; \operatorname{Rf} 2=0.55 ; \operatorname{Rf} 3=0.66$ \\
F12 & 14 & Rf $1=0.20 ; \operatorname{Rf} 2=0.51$ \\
F13 & 27.67 & Rf $1=0.08 ; \operatorname{Rf} 2=0.16 ; \operatorname{Rf} 3=0.23$ \\
F19 & 39.33 & Rf $1=0.08 ;$ Rf $2=0.16 ; \operatorname{Rf} 3=0.29$ \\
F20 & 14.67 & Rf $1=0.13$ \\
\hline
\end{tabular}


MIC of $0.01 \%$. Betel leaf extract with a concentration of $0.03 \%$ was able to inhibit the growth of $F$. oxysporum f.sp. capsici by $100 \%$, and at a concentration of $0.017 \%$ was able to inhibit the growth of $F$. oxysporum f.sp. capsici on the bell pepper stems by $100 \%$. Fractionation of betel leaf extract using column chromatography resulted in seven fractions that had inhibitory power against $F$. oxysporum f.sp. capsici. This showed that the betel leaf extract containeds several compounds with antifungal properties.

\section{ACKNOWLEDGMENT}

The author would like to thank the Head of the Biopesticide Laboratory, Udayana University for the facilities and infrastructure that the author can use during this research.

\section{REFERENCES}

Abdelmajeed NA, Danial EN, \& Ayad HS. 2013. The effect of environmental stress on qualitative and quantitative essential oil of aromatic and medicinal plants. Arch. Sci. 66(4): 100-120.

Ali I, Khan FG, Suri KA, Gupta BD, Satti NK, Dutt P, Afrin F, Qazi GN, \& Khan IA. 2010. In vitro antifungal activity of hydroxychavicol isolated from Piper betle L. Ann. Clin. Microbiol. Antimicrob. 9: 1-9.

Andrews JM. 2001. Determination of minimum inhibitory concentrations. J. antimicrob. chemother. 48. Suppl. SI: 5-16.

Aoki Y, Trung NV, \& Suzuki S. 2019. Impact of Piper betle leaf extract on grape downy mildew: effects of combining 4-allylpyrocatechol with eugenol, $\alpha-$ pinene or $\beta$-pinene. Plant Protect. Sci. 55(1): 2330 .

Arsih DW, Panggeso J, \& Lakani I. 2015. Uji ekstrak daun sirih dan cendawan Trichoderma sp. dalam menghambat perkembangan Fusarium oxysporum f.sp lycopersici penyebab penyakit layu Fusarium pada tanaman tomat. Natural Science: Jurnal Science and Technology. 4(3): 355-368.

Cahyono B. 2003. Cabai Paprika Teknik Budi Daya dan Analisis Usaha Tani. Kanisius, Yogyakarta.

Darmadi AAK. 2015. Isolasi dan Identifikasi Senyawa Aktif Ekstrak Daun Kayu Manis (Cinnamomum burmanni Blume) dan Uji Efektivitasnya dalam Mengendalikan Penyakit Layu Fusarium pada Tanaman Tomat yang disebabkan oleh Jamur Fusarium oxysporum Forma Specialis lycopersici. Laporan Akhir Penelitian Disertasi. Universitas Udayana, Bali.

Datta A, Ghoshdastidar S, \& Singh M. 2011. Antimicrobial property of Piper betel leaf against clinical isolates of bacteria. IJPSR. 2(3): 104-109.

Foo LW, Salleh E, \& Mamat SNH. 2015. Extraction and qualitative analysis of Piper betle leaves for antimicrobial activities. IJETSR. 2: 1-8.

Gnanasekaran P, Salique SM, Panneerselvam A, \& Umamagheswari K. 2015. In vitro biological control of Fusarium oxysporum f. sp. cubense by using some Indian medicinal plants. Int. J. Curr. Res. Aca. Rev. 3(11): 107-116.

Morales G, Sierra P, Mancilla A, Paredes A, Loyola LA, Gallardo O, \& Borquez J. 2003. Secondary metabolites from four medicinal plants from Northern Chile: antimicrobial activity and biotoxicity against Artemia salina. J. Chil. Chem. Soc. 49(1): 44-49.

Murugesan S, Vijayakumar R, \& Panneerselvam A. 2011. Antifungal activity of medicinal plants against plant pathogenic fungus Fusarium oxysporum. J. Pharm. Res. 4(3): 843-844.

Neela FA, Sonia IA, \& Shamsi S. 2014. Antifungal activity of selected medicinal plant extract on Fusarium oxysporum Schlechtthe causal agent of Fusarium wilt disease in tomato. Am. J. Plant Sci. 5(18): 2665-2671.

Patil RS, Harale PM, Shivangekar KV, Kumbhar PP, \& Desai RR. 2015. Phytochemical potential and in vitro antimicrobial activity of Piper betle Linn. leaf extracts. J. Chem. Pharm. Res. 7(5): 10951101.

Pagare S, Bhatia M, Tripathi N, Pagare S, \& Bansal YK. 2015. Secondary metabolites of plants and their role: overview. Curr. Trends Biotechnol. Pharm. 9(3): 293-304.

Phabiola TA. 2004. Penggunaan Ekstrak Beberapa Jenis Tumbuhan untuk Mengendalikan Penyakit Layu Pisang pada Pembibitan dari Bonggol. Tesis. Universitas Udayana, Bali.

Rahardjo M, Rosita SMD, Fathan R, \& Sudiarto. 1999. Pengaruh cekaman air terhadap mutu simplisia 
pegagan (Centella asiatica L.). J. Littri. 5(3): 92-97.

Rongai D, Pulcini P, Pesce B, \& Milano F. 2014. Antifungal activity of some botanical extracts on Fusarium oxysporum. Open Life Sci. 10(1): 409-416.

Sanit S. 2016. Antifungal activity of crude extracts of some medicinal plants against Fusarium sp., the pathogen of dirty panicle disease in rice. J. Med. Plants Res. 10(19): 248-255.

Singha IM, Kakoty Y, Unni BG, Kalita MC, Das J, Naglot A, Wann SB, \& Singh L. 2011. Control of Fusarium wilt of tomato caused by Fusarium oxysporum f.sp. lycopersici using leaf extract of Piper betle L.: a preliminary study. World J. Microbiol. Biotechnol. 27(11): 2583.
Singburaudom N. 2015. Hydroxychavicol from Piper betel leave is an antifungal activity against plant pathogenic fungi. JBiopest. 8(2): 82-92.

Subrata IM \& Rai IGA. 2019. Aktivitas fungisida ekstrak daun sirih (Piper betle L.) kultivar beleng terhadap jamur Fusarium oxysporum f.sp. vanillae penyebab penyakit busuk batang pada vanili. J. EMASAINS. 8(1): 41-50.

Suprapta DN \& Khalimi K. 2012. Anti-fungal activities of selected tropical plants from Bali Island. Phytopharmacology. 2(2) 265-270.

Trisilawati O \& Pitono J. 2012. Pengaruh cekaman defisit air terhadap pembentukan bahan aktif pada purwoceng. Bul. Littro. 23(1): 34-47. 